\title{
Psycholinguistic Potential of Political Concepts of the Election Campaign (on the example of the slogan-motto "Army. Language. Faith.")
}

\section{Психолінгвістичний потенціал політичних концептів передвиборчої кампанії (на прикладі слогану-гасла "Армія. Мова. Віра.")}

Natalia Koch

Dr. Sc. in Philologi,

Professor

\section{Наталя Коч}

доктор філологічних наук, професор

E-mail: nataliakoch62@ukr.net https://orcid.org/0000-0002-6663-4802

Svitlana Kaleniuk

Ph.D. in Philologi,

Associate Professor
Світлана Каленюк

кандидат філологічних наук, доцент

E-mail:kalenukso@gmail.com

https://orcid.org/0000-0002-6055-8351

Mykolaiv National Universiti of

V.O. Sukhomlynskyi (Ukraine)

24, Nikolskaya Str., Mykolaiv, Ukraine, 54030
Миколаївський національний університет імені

В.О. Сухомлинського (Украӥна)

$\triangle$ вул. Нікольська, 24, Миколаїв,

Україна, 54030

Original manuscript received January 21, 2021

Revised manuscript accepted September 30, 2021

\section{ABSTRACT}

The aim of the study is a psycholinguistic analysis of the stimulus words (Ukrainian) army, language, faith as concept-forming nominations of the appropriate text concepts in the structure of the slogan-motto (advertising slogan, political slogan) 
"Army. Language. Faith." the 2019 election campaign (that is, in the context of a particular discursive practice).

Methods of the research. The application of the method of free associative experiment basing on the theory of speech influence allows to interpret the semantics of the analyzed concepts, as well as to establish their closest connections and logical relationships with other concepts. Verbal reactions to a political slogan as a whole and to its individual structural units as concept-forming nominations are interpreted as verbal representations of cognitive features of concepts.

Results. The results of the associative experiment are a relevant source of data in order to identify markers of the deep (including subconscious) mechanisms of verbal and non-verbal behavior of individuals, which can be used to form new and transform old political concepts. The presence of intersecting segments in their semantic fields testifies about the partial synthesis of diverse concepts in the recipients' minds, in which the effect of the psycholinguistic influence of the slogan-motto is increased. The absence of such an intersection is an indicator of the information the general information field of the concepts, which is expressed in the discrete perception of the advertising slogan.

Conclusion. In the context of the speech theory influence, the first two stages of implementation the text slogan-motto "Army. Language. Faith." into mass consciousness (attracting attention to the text and optimization its perception) were successfully implemented. A number of reasons (extralinguistic and linguistic formation, for example, the use of words with abstract, non-specific semantics "language", "faith") complicated the implementation of the third stage (acceptance of the content) of the implication of the text. Concept-forming nomination "army", potentially containing negative semantic components, caused reactions associated with the emergency of cognitive disbalance in the consciousness of individuals. Comparison of the associates of the two stages of the experiment showed that the context of perception of the stimulus words is important for the respondents. Thus, the evaluative connotations of reaction words (in particular, concerning the nomination "army") in the context of the advertising campaign of P. Poroshenko's party and outside this context differ significantly.

Key words: political communication, theory of speech influence, political concepts, associative experiment, slogan-motto.

\section{Introduction}

The trend of the modern scientific paradigm - the integration of basic research theories developed both in traditional science (classical linguistics, cognitive psychology, sociology) and in certain interdisciplinary areas (for example, psycholinguistics, sociolinguistics, political linguistics) - relates to the focus of knowledge system on 
the practical needs of society. Some of these requests refer to political discursive practices and models of mass communication, which were successfully studied by American and European scholars of the mid-20th century. Modern foreign scientists create their own concepts of language actualization in political communication. Thus, Lakoff (2014) describes the effect of cognitive strategies in American politics; Chudinov (2016) successfully develops a method of linguistic analysis of the Russian political text; Dulebová and Štefančík (2017) investigate the problems of the Slovak conflict political discourse; Clementson (2018) provides experimental confirmation to the theory of manipulating information among the masses, etc.

Within the framework of speech influence theory, developed in the works of Leontiev (2003) and his colleagues, the texts of "socially oriented communication", mainly related to political communication in the USSR, were studied. Leontiev, a well-known psycholinguist, consistently defends the idea that all stages of the actualization of such a text (drawing attention to it, optimizing its perception and acceptance of its content by recipients) occur in the course of speech influence as a "deliberate restructuring" of a personality's semantic sphere (author's term - "personal meanings") (Ibid: 259).

The ultimate relation of a personality's semantic sphere to the cognitive processes of thinking makes the former an object of research in cognitive psychology, and the fact that meanings, as a rule, are verbalized, makes it an object of cognitive linguistics. It is the anthropocentric trend in modern linguistics that, while developing its own methodology, actively uses psycholinguistic methods in its research arsenal to verify the results of the linguistic material analysis (Popova \& Sternin, 2007).

Language as a powerful tool of speech influence is studied in cognitive linguistics not as such, but as the main material form of concept representation - a unit of our consciousness, which is defined as the "operational meaningful units of memory, mental vocabulary, conceptual system and the language of the brain, the whole picture of the world reflected in the human mind" (Kubryakova et al., 1996: 90). This definition naturally complies with the psychological (logical, psycholinguistic) direction of modern cognitive linguistics. In Ukrainian linguistics, this approach is implemented in the works of Selivanova (2010), who suggests studying the concept as a multisubstrate informational structure of consciousness (p. 292). 
In our study, the idea of conceptualizing a word, which nominates a concept, with the corresponding action in the communication process is important. Therefore, the recognition of the fact that a concept contains cognitively and communicatively relevant information that participates in the formation of worldview, value systems, etc., makes it an object of close attention of specialists in the field of political linguistics, as well as political strategists dealing with the practical issues of creating effective texts that are able not only to form a concept, but also "deliberately restructure" it (Leontiev, 2003).

Psycholinguists are appealed by cognitivists' stance that a concept (or its cognitive features) can be represented as an associative and verbal semantic node (Popova \& Sternin, 2007). Such nodes are modeled lexicographically in associative dictionaries, the materials of which are widely used by specialists in the field of communication. For example, the data of the "Short Associative Vocabulary of Advertising Slogans" allow to predict both effective and undesirable associations for an advertising message (Kutuza \& Kovalevska, 2011). The Achilles' heel of such dictionaries is the dependance of their results on the dynamicity of linguistic consciousness that changes under the influence of sociocultural and other factors. Therefore, systematic associative experiments aimed at identifying the real semantic connections between words in a specific time and space continuum is necessary for an objective assessment of the process of understanding a particular fragment of the world picture (a concept) "here and now". For political strategists the results of such experiments are a relevant source for compiling special texts, serving as markers of the deep (including subconscious) mechanisms of the individual's verbal and non-verbal behavior, which can be used to form new and transform old political concepts. Obtaining similar experimental data is the goal of our empirical research, which involves a certain methodology, developed in sufficient detail at this time by a number of both domestic and foreign psycholinguists (Ludueña et al., 2014; El-Dakhs, 2017; Vivas et al., 2019).

\section{Methodology of empirical research}

The objective of our research is a psycholinguistic analysis of the stimulus words army, language, faith (армія, мова, віра - in Ukrainian) 
as concept-forming nominations of the corresponding text concepts in the structure of "Army. Language. Faith.", the slogan-motto (advertising slogan, political slogan) of the 2019 presidential election campaign in Ukraine (i.e. in the context of a specific discursive practice).

Psycholinguistic analysis of stimulus words fits organically into empirical research, which uses an experiment as one of the main methodological techniques. The free associative experiment was carried out in two stages. The first stage was held at the beginning of 2019 (before the elections), while the second stage was performed at the end of 2020. At the first stage, the subject of the experiment was the advertising slogan "Army. Language. Faith" as a coherent text. At the second stage, concept-forming nominations language, life, army, stability, faith (the words life and stability were introduced intentionally to break down the slogan in order to avoid direct associations with the slogan (the so-called background stimuli); for the same reason, the order of components was changed). The change in the procedure at the second stage is explained by the intention to confirm the hypothesis about the predominantly discrete perception of the concepts of the slogan and thus to verify the research. There were no restrictions in the form of expression of reactions (grammatical, semantic).

The empirical dataset with detailed quantitative and qualitative characteristics of the sample is available on the Zenodo International Repository (Koch \& Kaleniuk, 2021).

\section{Research methods and techniques}

Psycholinguistic research of the slogan "Army. Language. Faith." requires the use of appropriate methods. The application of the method of free association experiment supported by the persuasion theory allows one to interpret the semantics of the analyzed concepts, as well as to establish their closest connections and logical relations with other concepts. Associative verbal reactions to a political slogan as a whole or to its structural units as independent stimulus words (they also being concept-forming nominations) are interpreted in the course of a free associative experiment as verbal representations of cognitive features (both integral and differential ones) of the concepts ARMY, LANGUAGE, FAITH. Such features make up their structure and are 
ranked in terms of their intensity. Thus, a psycholinguistic experiment, the purpose of which is to record verbal responses to corresponding stimuli, allows one to model the content of concepts in the form of a field with a nuclear and peripheral organization of the structure. The presence of overlapping segments of the fields of these concepts will indicate a partial synthesis of diverse concepts in the minds of the recipients, which enhances the effect of the psycholinguistic influence of the slogan. The absence of such an overlapping will indicate the lack of the common information field of concepts, which can be expressed, for example, in a word-by-word (inconsistent, discrete) perception of a political slogan.

\section{Participants}

Students of faculty of pedagogy and psychology, pedagogical and social education, philological faculty of Mykolayiv National University named after V.O. Sukhomlinsky participated in a free associative experiment. The age of male and female respondents (120 people) ranged from 17 to 25 years old. The choice of the audience for the experiment was not accidental. As psycholinguists rightly noted, by the age of 25 , a person is an already formed linguistic personality, characterized by the stability of cognitive features. This makes it possible to use the obtained experimental material for prognostic and diagnostic purposes to analyze the dynamics of mass consciousness processes in the society of the future.

\section{Adherence to ethical standards}

The research was conducted in accordance with the requirements of the Research Ethics Committee, which was discussed at the meeting of the Department of General and Applied Linguistics of Mykolayiv National University named after V.O. Sukhomlinsky. The experiment procedure was agreed with the respondents, which is documented (Protocol № 2 from 03.09.2020). The experiment was not funded. There is no conflict of interest. 


\section{Results}

At the first stage of the experiment, the informants were presented with a list of advertising slogans of the parties participating in the 2019 election race (50 slogans). Slogan "Army. Language. Faith." was included in this list at number 30. The informants were given the following task: to write down the first three verbal reactions to the stimulus slogans that come to mind. 196 reactions were recorded to the analyzed political text (16 refusals, 49 people - one reaction, $19-$ two reactions, 35 - three reactions, 1 - four reactions). After counting repetitive and single reactions, we identified nuclear and peripheral structures of the verbal-associative field of the political slogan "Army. Language. Faith." (196/117/75). At the second stage of the experiment, 114 respondents (6 refusals) provided us with 1080 responses-reactions to the stimulus words army, language, faith, of which 823 were repeated, 265 were single) $(1080 / 823 / 265)$.

What is peculiar about the structuring of the associative field of the slogan "Army. Language. Faith." and stimulus words army, language, faith is that to the total number of repetitive reactions in the original form, we added verbal reactions of one word-building nest, different grammatical forms with a common root, as well as phrases with a similar reference (grammatically or semantically) word. At the second stage of the experiment, the reactions of male and female respondents (I (m); II (f)) were calculated separately, although a small number of the former did not give grounds for gender-based conclusions.

At the first stage of the experiment, a number of simple and complex sentences, which formally (grammatically) were one reaction, but semantically related to the three components of the slogan, were broken by us into three reactions, but written as one answer in square brackets: [Be sure to serve in the army. Love the language. Don't betray your faith]; [Every man has to go this way, know your mother tongue, believe in your country]; [Forge swords into plows, encourage learning through language awareness, believe in success]; [Do not forget the army, language and believe in our country]. The difficulty in calculating reactions was related to the interpretation of syntactic constructions. For example, the cliché sentences "This is not a motto. This is a formula of the current Ukrainian identity", a number of nominative sentences 
"nonsense, thinking by wrong categories, mental retardation", "and that's all? reforms? salary?", "all achievements for five years", "drifting stereotypes" were interpreted by us as one reaction to the slogan taken as a whole.

According to the results of the first stage of the research, the core of the pre-election slogan is represented by the following verbal reactions: war (11) + [Army] of war, + endless war (13 total); hope (11) + hope for a better future, + hope in Ukraine (13 total); Poroshenko (8) + P. Poroshenko (3), + Petro Poroshenko, + the fifth president of Ukraine (13 total); force (9) + force (2) (11 total); protection (4) + what (we) have to protect $(2),+$ protection of the country, + element of protection (8 total); Ukraine (4) + Ukraine above all; + this is our strong Ukraine; + Ukraine is a strong state (7 total); future (6); peace (3) + peaceful sky, + only peace, + peace in the country (6 total); patriot (2) + patriot (I am not a patriot), + patriots, + patriotism (2) (6 total); nation + strong nation, + foundation of the nation, + nationalism (4 total); victory (3) + Victory (4 total); solidarity (2) + European solidarity + EU (4 total); belief that everything in the country will be alright + believe + believe (total 3); state (3); unity (2) + union (total 3); country + country foundation (2) (3 total); love (3); church + churches + Ukrainian Autocephalous Church (3 total); defending one's nationality + defending one's views (2 total); people (2) (117 reactions in total).

Sporadic reactions in the form of words, phrases, and sentences (including complex ones) represent the periphery of the associative field of the slogan: [Be sure to serve in the army. Love the language. Do not betray the faith]; ATO (anti-terrorist operation); Homeland; fighters; pain; inaction; nonsense, unreal; the lie of Peter Waltzman; important aspects; responsibility; troops; Vilkul; water, no specifics; influence; all achievements over the last five years; money, discrimination (by language), Democracy!; home; life; obsolete; and that's all? reforms? salary?; beauty; [Every man has to go this way, know your mother tongue, believe in your country]; it would be better without an army; slogan; [delusion, thinking in the wrong categories, mental retardation]; [Forge swords into plows, encourage learning through language awareness, believe in success]; we; past centuries; can I reduce the term of service???; courage; NATO; immunity, [do not forget the army, language and believe in our country]; Not always; independence; inviolability; untidiness; incompatible things; No!!!; 
promises; duty; respect; political control; truth; regime; religion; Russia; roshen (Roshen Confectionery Corporation, a company owned by Petro Poroshenko, the participant of 2019 presidential election campaign); self-improvement; consciousness; freedom; components of any state; components that are important in Ukraine; word; death; nightingale; hope; tranquility; drifting stereotypes; reduce the term of service; the Ukrainian language; this is not a slogan. This is the formula of modern Ukrainian identity; sweets; XIX century, ... (75 reactions in total).

Let us note some tendencies in the responses of recipients at the first stage of the experiment. Grammatical verbal reactions to the slogan are represented by words, phrases, and sentences. The dominant structural relations in the core of the associative field are paradigmatic. They expand and clarify the semantics of stimulus words and thus reveal the cognitive features of the corresponding concepts. The presence of syntagmatic associations indicates speech relations within the peripheral structure of the associative field, reflecting not so much the cognitive structure of the linguistic consciousness of a group of respondents, as their individual meanings.

As a rule, three verbal reactions corresponded to three components of a slogan, for example: protection, responsibility, courage; protection, word, soul; protection, religion, nation; Pain, Nightingale, Hope; NATO, Ukrainian language, Ukrainian Autocephalous Church; future, state, I believe; strength, beauty, hope; money, discrimination (by language), peace in the country; Forge swords into plows, encourage learning through language awareness, believe in success; Every man has to go this way, know your mother tongue, believe in your country; Be sure to serve in the army. Love the language. Do not betray the faith. Less frequently, the reaction(s) concerned only one of the three components, apparently, the most relevant in the minds of respondents [stimulus "Army"]: war; fighters; defending one's views; poverty; it would be better without an army; inviolability; patriot(s); patriotism; victory; power; strong nation; death; foundation of the country.

Some of the respondents presumably perceived the slogan as a cohesive text presenting one reaction in the form of a word, a phrase, or a sentence, e.g.: Democracy!; state; country; future; hope; independence; truth; patriot; patriot (I am not a patriot); patriots; Ukraine; important components in Ukraine; delusions, thinking in the wrong categories, mental retardation; Ukraine is a strong state; this is our strong Ukraine. 
If we follow the hypothesis of discrete interpretation of a slogan, then the initial position of reactions of the type force (11); protection (4) + what (we) have to protect (2), the protection of the country, the element of protection, which expresses one of the basic human needs to be safe and secure, indicates their relation to the ARMY concept. The same need motivates the emergence of associations such as future (6), peace (3) + peace in the country, peaceful sky, only peace, which are semantically opposed to the word war.

Both negatively $(44.0 \%)$ and positively $(56.0 \%)$ colored reactions of rational, evaluative, and emotional nature were recorded for the "Army" stimulus (as the most actualized concept in the minds of informants): war (11) + endlesswar, + army of war; force (11); Be sure to serve in the army; pain; defending one's nationality; defending one's views; money; protection (4) + what (we) have to protect (2), + protection of the country, + element of protection; poverty; Every man has to go this way; it would be better without an army; Forge swords into plows; can I reduce the term of army service???; not to forget the army; inviolability; No!!!; death; reducethe service life; patriotism; victory; strongnation; death; Thefoundationof the country. Emotional and evaluative associations, reflecting the figurative and value structures of the concept, show their socio-cultural (in this case, situational) conditionality. Rational associations carry information about the factual (conceptual) layer of the concept. Reactions such as anti-terrorist operation, NATO, fighters do not contain evaluation, but indicate the awareness of the political context (see below on the ambivalence of the perception of the ARMY concept).

In accordance with the abovementioned, particularly interesting seem to be some statements and words that are imperative and/or evaluative: Be sure to serve in the army. Love the language. Do not betray the faith; nonsense, unreal; Peter Waltsman's lie; water, no specifics; influence; money; and that's all? reforms? salary?; Every man has to go this way, know your mother tongue, believe in your country; it would be better without an army; nonsense, thinking in the wrong categories, mental retardation; Forge swords into plows, encourage learning through language awareness, believe in success; not to forget the army, language and believe in our country; can I reduce the term of army service???; not always; No!!!; promises; political control, regime; 
Psycholinguistic Potential of Political Concepts of the Election...

drifting stereotypes; reduce the service in the army; what we have to protect; one must believe; Ukraine above all.

Reactions like Poroshenko (8), P. Poroshenko (2), Petro Poroshenko; the fifth President of Ukraine, the lies of Petro Waltsman, solidarity (2), European solidarity, EU indicate the formation of informational and emotional attachment to the name of a politician and a political party. Associates such as roshen, sweets show the overlap of two brands in the minds of the respondents - "P. Poroshenko is a politician" and "P. Poroshenko is a businessman". Awareness of the authorship of the slogan was also expressed by reactions such as all achievements in the last five years, citations of the president's agitation statements that have become speech cliches: This is not a slogan, this is a formula of modern Ukrainian identity; Ukraine above all.

The analysis of the results obtained during the second stage of the experiment made it possible to structure the fields of the political slogan concepts separately:

Army I (m) (23/23) defense (5); force (4) + strong (1) (5); war (4); weapons (4); security (3); hope (2); debt; faith; great; volunteers, dignity; roar; smoke; blood; power; courage; patriotism; victory; tears; death; soldiers; tranquility; strategy; fear; physical training; physical strength; form; red.

II (f) $(273 / 63)$ defender (1) + defenders $(3)+$ protection $(\mathbf{2 8})+$ safety (1) (33); force (25) + strong (3) + armed forces (2) (30); war (25); courage (17) + courageous (1) (18); discipline (11); weapons (11); soldier (8) + soldiers (2) (10); reliable (1) + reliability (3) + hope (4) (8); service (8); courage (5) + brave (1) (6); pain (5); form (5); defense (5) + defense (1) (6); troops (2) + army (1) + military (1) (4); duty (3) + mandatory (1) (4); tranquility (4); battle (1) + fight (1) + combative (1) (3); struggle (3); faith (1) + loyalty (2) (3); warrior (2) + militancy (1) (3); mighty (3); oath (3); men (1) + masculine (1) + for men (1) (3); Homeland (2); security (2); great (1) + greatness (1) (2); state (2); unity (2); beloved (1) + love (1) (2); blood (2); peace (2); violence (1) + violence (1) (2); amulet (1) + amulet of the state (1) (2); patriotism (2); support (2); victory (2); courage (2); death (2); fear (2); boys (1) + young boys (1) (2); aggression; ATO; agitation brigade; indifference; parents; fearlessness; charity; armor; long term; devotion; responsibility; distance; eternity; enemy; heroes; famine; grief; valor; trust; domination; friend; victim; dugout; poverty; strong; 
conflict; bullets; puppet; mother; mobility; peaceful sky overhead; learning; people; population; independence; invincible; inviolability; misfortune; support; person; expectation; respect; field; order; year; separation; devastation; movement; tears; sorrow; stability; strategy; shooting; austerity; sovereignty; resistance; tank; company; anguish; front; honesty; black.

Language - I (m) (10/35) communication (3); Ukrainian (3); homeland (2); nightingale (2); free; expressing an opinion; state; dialect; thoughts; means of communication; ability; knowledge; guelder rose; flowering; communication; border; country; culture; linguistics; opportunities; teaching; hope; people; song; write; flag; native; kinship; conversation; Russian; self-identification; heart; system; words; word; listen; community; society; TV.

II (f) $(238 / 53)$ native (31) + ancestry (1) + family (1) + birth (1) (34); Ukrainian (12) + Ukraine (11) (23); communication (14) + means of communication (1) (15); nightingale (12) + nightingale (1) + nightingales (1) (14); melodic (8) + melody (2) (10); word (4) + first words of a mother (1) (10); melodious (9); people (8) + folk (1) (9); nation (7) + national (1) + nationality (1) (9); treasure $(8)+$ treasury (1) (9); words (4) + dictionary + Homeland (8); state + state (6) (7); communication (6); unity (6); maternal (2) + mom (1) + mother (1) + mama (1) (5); melodiousness (5); foreign (3) + foreigner (1) (4); conversation (4); songful (4); school (4); conversation (3); embroidered shirt (3); childhood (3); code (1) + nation code (2) (3); song (3); pure (3); English (2); teacher (2); pretty (2); pride (2); guelder-rose (2); flower (2); book (2); country (2); literature (2); man (2); patriot (1) + patriotism (1) (2); understanding (2); traditions (1) + tradition (1) (2); multifaceted; interaction; exercise; harmonious; speaking; voice; dialect; dictation; source; soul; essay; life; means of thinking and communication; weapon; communication; clear; identification; individuality; interest; intonation; beauty; easy; linguistics; possibility; wisdom; the best; population; science; tender; independence; textbook; songs; poetry; understanding; required; thing; work; power; symbol; sense; heritage; rest; calm; article; university; unique; success; value; charming; wonderful; sincere; tongue.

Faith - I (m) (18/27) hope (6) + reliability (1) (7); God (3); confidence (2); soul (2); future (2); religion (2); atheism; balance; feeling; believers; kindness; trust; friendship; Spiritual power; name; truth; 
space; love; goal; prayer; best; sanctify; support; gratitude; principles; prudence; holiness; hope; stability; church; value; miracle; happiness.

II (f) $(261 / 64)$ reliability (1) + hope $(28)+$ hope for the best (1) (30); religious (1) + religion (19) (20); love (18); the future (16); God (13) + god (1) + in God (1) (15); spiritual content (1) + spirituality (6) + soul (7) (14); hope (11); prayer (8) + prayers (1) (9); strength (8) + strength of spirit (1) (9); church (9); life (7); confidence (7); trust (6); inspiration (6); in oneself (4); friend (1) + friendship (2) + friends (1) (4); love (4); family (4); desire (3); heights (2) + height (1) (3); in better (1) + in the best (1) + improvement (1) (3); good (3); ); expectations (3); support (3); feelings (3); happiness (3); angel (2); grace (2); only (1) + unity (1) (2); name (2); dream (2); light (2); tradition (1) + tradition of the people (1) (2); success (2); Bible; hopelessness; nature; devotion; relationships; feeling; belief; in love; into a happy future; in happiness; dove; day; help; thirst; mystique; changes; knowledge; truth; collapse; better; people; humanity; human; goal; peace; property; naivety; people; mood; indifference; sky; nothingness; unique; infinity; new beginning; amulet; wedding ring; memory; belief; truth; Orthodoxy; desire; beam; request; paradise; consolation; mind; world; freedom; own; holiness; sun; justice; hardness; in humans; warm; care; fantasy; clouds; Christian; goals; purity; miracle; sincerity.

Paradigmatic associations dominate in the experimental results: there are 143 syntagmatic reactions $(13.0 \%)$ and 955 paradigmatic reactions $(87.0 \%$. The prevailing number of repetitive reactions $(823$ $(76.0 \%)$ out of 1088$)$ testifies to the stereotyped thinking of young people, primarily due to their conventional education and upbringing as well as to the influence of the media.

The most striking cognitive features of verbal stimuli army, language, faithare respectively: "defense function", "qualitative characteristic of force", "conduct of hostilities"; "family affiliation", "national self-identification", "way of communication"; "attitude towards hope", "religious category", "attitude towards love". Their semantic similarity is determined by the number of semantic overlappings in the reactions of Homeland, faith, state, soul, life, weapons, hope, strength. The presence of similar reactions (except for soul and weapons) at the first stage of the experiment indicates the stable formation of the semantic connection between the concepts HOMELAND, FAITH, STATE, LIFE, HOPE, POWER, which can be successfully used for the 
creation of targeted advertising texts: hope (11) + hope for Ukraine + hope for a better future; strength (9) + strength (2); belief that everything in the country will be alright + faith + belief in success + belief in our country + believe in our country + you need to believe; state + elements of any state + Ukraine is a strong state; Homeland; life.

\section{Discussion}

Let us comment on the results of the second stage of the psycholinguistic experiment, which are important in the context of our study. The first remark concerns the responses containing reactions to the stimulus word army. Most of the answers were semantically consistent, for example: discipline, respect, support; protection, war, patriotism; service, discipline, oath; service, war, soldier; protection, peace, tranquility; war, weapons, power vs puppet, violence, victim; tears, separation, longing; military, war, grief; pain, hunger, black; fear, smoke, roar; pain bullet devastation. Existence of such reactions as protection, tranquility, war; death, conflict, support; security, peace, tears; protection, fear, strength; force, aggression, unhappiness, in which there is a semantic discrepancy in relation to one subject (in this case, to the ARMY concept), indicates, in terms of cognitive psychology, the presence of cognitive conflict in the mind of an individual. Such a phenomenon can be interpreted based on various psychological and sociological theories. Our interpretation of this phenomenon is based primarily on Levin's and Cartwright (1963) field concept, in particular their ideas that the behavior of the individual is determined by their "living space", and the cause of conflict behavior is a situation in this space, in which a person is simultaneously influenced by opposite valences of equal magnitude. It is important that these opposites are formed because of their subjective perception, and therefore are endowed with subjective meanings. The experimental data demonstrate the type of conflict in which consciousness is "attacked" by two opposing forces (meanings, ideas, needs, etc.) of a positive and negative nature: the internal need for a peaceful, safe, peaceful life and the external influence of living space factors associated with patriotic mood and support for the soldiers of the Ukrainian army. This is a complex type of conflict that is both intrapersonal and interpersonal. 
If we consider the associative field of a stimulus word as a structured system, in which the corresponding object must be assigned to a certain category, evaluated positively or negatively, then the psychological balance in such a system is determined by semantically consistent valences. The imbalance of the perceptual field, indicating a cognitive inconsistency, is reflected by groups of associates such as safety, tranquility, tears. They cause psychological discomfort, which can manifest itself in the form of anxiety, depression, etc. In this case, the cognitive system strives for its reorganization aimed at avoiding discomfort: the object of perception is simultaneously presented in consciousness with both a plus and a minus sign.

Verbal reactions with a negative connotation are predictably recorded in the responses to the stimulus word army both at the first and at the second stage of the experiment: Stage I - war (11) + war + endless war + Army. ... wars; pain; money; poverty; it would be better without an army; Forge swords into plows; can I reduce the term of army service???; No!!!; death; reduce the term of army service (23 total (44.0\%) out of 52); Stage II - war (29); pain (5); blood (3); fear (3); violence (1) + violence (1) (2); death (2); aggression; indifference; famine; grief; victim; poverty; conflict; bullets; puppet; a place where people are broken; misfortune; separation; devastation; tears; sorrow; anguish; black (total $57(15.0 \%)$ out of 382). As can be seen, the connection between the concepts ARMY and WAR in the minds of respondents is most relevant, which is confirmed by the results of two stages of associative experiment: at the first stage the reaction word war is used 14 times, in the second - 29 (43 total). It should be noted that the negative perception of the word army dominates in the responses to the political slogan. Outside the context of elections, this concept-forming nomination is represented mainly by semantically positive reactions $(85.0 \%$ vs $15.0 \%)$. As a result, the number of associates determines the brightness of the cognitive features of the ARMY concept, associated with the concepts DEFENSE, FORCE and WAR.

Certainly, the actualization of words in the answers is not accidental and depends on the specific situation in the country, i.e. military operations in the east of Ukraine. This research confirms our assumption of discrete perception of the slogan and the dominance of the first element in it. Such domination was also evident in the 
responses, when the reaction(s) referred only to the first word: War, defending one's nationality; hope, victory, war; Patriots.

\section{Conclusions}

The idea that the precise qualification of verbalized concepts is of paramount importance in a political text is significant for the pragmatic goals of modern political communication. The blurriness of the semantics of abstract concepts used by politicians, which is further complicated in the process of perception by the "multiplication" of meanings, their cultural symbolism and social determinedness are both an advantage and a stumbling block for the authors of politically oriented texts. The psycholinguistic specificity of words is more vividly manifested in the transitional or critical periods of the social development, mentally "going through" a series of election campaigns. Therefore, the study of this specificity with the help of an associative experiment can help specialists in the field of political communication, whose task is to analyze the axiological models of society, its conceptually objectified convictions and beliefs formed because of an impact (a speech one, in particular) directed at the human mind.

The slogan "Army. Language. Faith." addressing the mass voter, expressed the ideology of Petro Poroshenko Bloc in general and the idea of Petro Poroshenko's election campaign and his political image in particular. The specific feature of the text is its genre specificity associated with its attribution to both a propaganda slogan and an advertising slogan. The imperativeness, evaluativity and emotionality, usually explicated in a slogan, are implicitly presented in the text, as in advertising, which can be concluded through the imperative and evaluative associations of the respondents.

Having chosen for his political program three impactive "pillars" the key strategic concepts ARMY, LANGUAGE, FAITH, P. Poroshenko, claiming a large-scale approach to solving important problems of Ukrainian politics, thereby outlined the rigid boundaries of the sphere of his influence and narrowed down the targeting of his message. The relevance and axiological markedness of the slogan concepts does not raise any doubts, however, a three-focus approach (usually one theme is postulated) caused the ideological redundancy (overload) of the text 
Psycholinguistic Potential of Political Concepts of the Election...

and thereby complicated its perception. The ambivalence of the concept ARMY became the reason for the emergence of cognitive dissonance in the minds of the respondents.

The results of the study confirmed a number of general conclusions drawn by psycholinguists regarding the recommendations for increasing the effectiveness of advertising slogans, political slogans, etc. The analysis of repetitive reactions makes it possible to determine the semantic constants that are relevant in the minds of the respondents, while the identification of overlapping reactions of stimulus words at two stages of the experiment makes it possible to reveal the common semantic field of words as concept-forming nominations, which means to prove the possibility of their potential combination in one text (here concepts HOMELAND, FAITH, STATE, LIFE, HOPE, POWER). The resulting concepts indicate the presence/absence of their associative connection with the key ideas of the party headed by P. Poroshenko (in this case, the connection with the concept FAITH is obvious).

Based on the psycholinguistic theory of speech influence, it can be stated that the first two stages of the implementation of the slogan "Army. Language. Faith." have been successfully realized by political technologists. Comparison of the words highlighted in Poroshenko's public speeches and the presence of semantically similar associations in the answers of respondents (for example: we, defense, defense of the country; element of defense; what (we) have to defend; independence; strength; this is our strong Ukraine; Ukraine is a strong state, the Ukrainian autocephalous church, the Ukrainian language, the components of any state, the components that are important in Ukraine, the people) testifies to the success of the politician's program speeches, which were delivered at the stage of attracting attention to the text. The widespread use of the slogan as an element of outdoor advertising helped to complete the stage of optimizing of its perception. The most difficult proved to be the third stage of the realization of the slogan as the quintessence of the election program - the acceptance of its content by the recipients - involving a "deliberate restructuring" (Leontiev, 2003) of the semantic sphere of personality. For several reasons, the perception of the content of the slogan as a whole did not occur. Thus, words with abstract, non-specific semantics complicated the understanding of the text, which hindered the activities of the copywriter associated with predictions of their perception (cf. associations of words 
language and faith). Lexemes with negative semantics (or potentially containing negative semantic components) cause a negative reaction, often associated with the emergence of cognitive inconsistency in the individual's consciousness, and as a result - psychological discomfort, rejection of background circumstances, appearance of negativity directed at the author of the advertisement (slogan), etc. This fact was proved by the results of the associative experiment with the stimulus word army. It is important to note that the comparison of the associates of the two stages of the experiment showed that the context (in a broad sense) of the perception of stimulus words is important for the respondents. Thus, the evaluative connotations of reaction words (especially those related to the army nomination) in the context of Poroshenko's party slogan and outside the context differ significantly.

So, the diagnostic and prognostic potential of a free associative experiment is beyond doubt. Obviously, the validity of the study implies additional research with using, in addition to the associative experiment, some other psycholinguistic methods and techniques, such as: psychosemantic differential, unfinished sentences technique, etc. Involvement of background knowledge (for example, relevant publications in the media), as well as linguo-conceptual analysis of the text constituents will enable us to realize a discursive approach to the study of concepts and to more reliably interpret the results of a free associative experiment aimed at identifying their cognitive features. It is obvious to us that the effectiveness of the final phase of collective consciousness modeling is advisable to discuss based on an additional linguo-cognitive analysis of slogan concepts using the already obtained results of associative experiments, which is a continuation of the study in the short term.

This experiment is of great importance for the study of linguistic consciousness in general, being the basic methodological technique for describing deep mental structures. In the context of persuasion theory, an associative experiment is designed to establish relevant meanings, conceptualized in the minds of the recipients with a certain notion. The system of such meanings determines the evaluative potential of the concept and, therefore, the possibilities of its effective impact on the intellectual and emotional structures of the mind of both an individual and a large group of people (in this case - the electorate). 


\section{References}

Chudinov, A.P. (2016). Obshhie voprosy politicheskoj lingvistiki. Teorija i metodika lingvisticheskogo analiza politicheskogo teksta [General questions of political linguistics. Theory and methodology of linguistic analysis of political text]. Ekaterinburg: Ural. gos. ped. un-t. [in Russian]

Clementson, D.E. (2018). Effects of Dodging Questions: How Politicians Escape Deception Detection and How They Get Caught. Journal of Language and Social Psychology, 37(1), 93-113. https://doi.org/10.1177/0261927X17706960

Dulebová, I., \& Štefančík, R. (2017). Securitization theory of the Copenhagen school from the perspective of discourse analysis and political linguistics. XLinguae, 10(2), 51-62. https://doi.org/10.18355/XL.2017.10.02.05

El-Dakhs, DAS. (2017). The Effect of Language Exposure and Word Characteristics on the Arab EFL Learners' Word Associations. Journal of Psycholinguistic Research, 46(4), 1033-1052. https://doi.org/10.1007/s10936-017-9477-z

Koch, N., \& Kaleniuk, S. (2021). Psycholinguistic potential of political concepts of the election campaign (on the example of the slogan-motto "Army. Language. Faith."). Zenodo. https://doi.org/10.5281/zenodo.5528207

Kubryakova, Ye.S., Demiankov, V.Z., Pankrats, Yu.G., \& Luzina, L.G. (1996). Kratkij slovar kognitivny hterminov [Concise Dictionary of Cognitive Terms]. In Ye.S. Kubryakova (Ed.). Moscow: M.V. Lomonosov Moscow State University [in Russian].

Kutuza, N.V., \& Kovalevska, T.Yu. (2011). Korotkyi asotsiatyvnyi slovnyk reklamnykh slohaniv [Concise associative dictionary of advertising slogans]. Odesa: Astroprint [in Ukrainian].

Lakoff, G. (2014). The ALL NEW Don't Think of an Elephant!: Know Your Values and Frame the Debate. White River Junction, Vermont: Chelsea Green Publishing.

Leontiev, A.A. (2003). Osnovy psiholingvistiki [Fundamentals of Psycholinguistics]. Moscow: Smysl; Saint Petersburg: Lan [in Russian].

Levin, K., \& Cartwright, D. (1963). Feldtheorie in den Sozialwissenschaften: ausgewählte theoretische Schriften. Bern: H. Huber.

Ludueña, G.A., Behzad, M.D., \& Gros, C. (2014). Exploration in free word association networks: models and experiment. Cognitive Processing, 15(2), 195-200. https:// doi.org/10.1007/s10339-013-0590-0

Popova, Z.D., \& Sternin, I.A. (2007). Kognitivnaja lingvistika [Cognitive Linguistics]. Moscow: AST Vostok-Zapad [in Russian].

Selivanova, O.O. (2010). Linhvistychna entsyklopediia [Encyclopedia of Linguistics]. Poltava: Dovkillya-K [in Ukrainian].

Vivas, L, Manoiloff, L, García, AM, Lizarralde, F, \& Vivas, J. (2019). Core Semantic Links or Lexical Associations: Assessing the Nature of Responses in Word Association Tasks. Journal of Psycholinguistic Research, 48(1), 243-256. https:// doi.org/10.1007/s10936-018-9601-8 


\section{АНОТАЦІЯ}

Метою дослідження $\epsilon$ психолінгвістичний аналіз слів-стимулів армія, мова, віра як концептоутворювальних номінацій відповідних текстових концептів у структурі слогану-гасла (рекламного слогану, політичного гасла) "Армія. Мова. Віра." передвиборчої кампанії 2019 р. (тобто, в контексті конкретної дискурсивної практики).

Методи. Застосування методу вільного асоціативного експерименту з опорою на теорію мовного впливу дозволяє інтерпретувати семантику аналізованих концептів, а також встановити їх найближчі зв'язки та логічні відношення з іншими концептами. Вербальні реакції на політичне гасло в цілому та на його окремі структурні одиниці як концептоутворювальні номінації інтерпретуються як словесні репрезентації когнітивних ознак концептів.

Результати. Результати асоціативного експерименту для політтехнологів $\epsilon$ релевантним джерелом даних із метою виявлення маркерів глибинних (в тому числі й підсвідомих) механізмів вербальної та невербальної поведінки індивідів, які можна використовувати для формування нових і трансформації старих політичних концептів. Наявність у їх семантичних полях сегментів, що перетинаються, свідчить про часткове синтезування різнопланових понять у свідомості реципієнтів, при якому посилюється ефект психолінгвістичного впливу гасла. Відсутність такого перетину $\epsilon$ показником несформованості загального інформаційного поля концептів, що виражається, дискретному сприйнятті рекламного слогана.

Висновки. У контексті теорії мовленнєвого впливу перші два етапи втілення тексту слогану-гасла "Армія. Мова. Віра." у масову свідомість (залучення до тексту уваги та оптимізація його сприйняття) були успішно здійснені. Ряд причин (зокрема екстралінгвістичного та лінгвістичного характеру, наприклад, використання слів з абстрактною, неконкретною семантикою "мова" та "віра") унеможливив здійснення третього етапу (прийняття змісту) імплікації тексту. Концептоутворювальна номінація "армія» як така, що потенційно містить негативні смислові компоненти, викликала реакції, пов'язані з виникненням у свідомості індивідів когнітивного дисбалансу. Порівняння асоціатів двох етапів експерименту показали, що для респондентів важливим є контекст сприйняття слів-стимулів. Так, оцінні конотації слівреакцій (зокрема тих, що стосуються номінації "армія") в контексті рекламної кампанії партії П. Порошенка і поза цього контексту істотно розрізняються.

Ключові слова: політична комунікачія, теорія мовленнєвого впливу, політичні концепти, асоціативний експеримент, слоган-гасло. 
Psycholinguistic Potential of Political Concepts of the Election...

Коч Наталия \& Каленюк Светлана. Психолингвистический потенциал политических концептов предвыборной кампании (на примере слоганалозунга "Армия. Язык. Вера.")

\section{АННОТАЦИЯ}

Целью исследования является психолингвистический анализ слов-стимулов армия, язык, вера как концептообразующих номинаций соответствующих текстовых концептов в структуре слогана-лозунга (рекламного слогана, политического лозунга) “Армия. Язык. Вера." предвыборной кампании 2019 г. (то есть, в контексте конкретной дискурсивной практики).

Методы. Применение метода свободного ассоциативного эксперимента с опорой на теорию речевого воздействия позволяет интерпретировать семантику анализируемых концептов, а также установить их ближайшие связи и логические отношения с другими концептами. Вербальные реакции на политический лозунг в целом и на его отдельные структурные единицы как концептообразующие номинации интерпретируются как словесные репрезентации когнитивных признаков концептов.

Результаты. Результаты ассоциативного эксперимента являются релевантным источником данных с целью выявления маркеров глубинных (в том числе и подсознательных) механизмов вербального и невербального поведения индивидов, которые можно использовать для формирования новых и трансрормации старых политических концептов. Наличие в их семантических полях пересекающихся сегментов свидетельствует о частичном синтезировании разноплановых понятий в сознании реципиентов, при котором усиливается эффект психолингвистического влияния слогана-лозунга. Отсутствие такого пересечения является показателем несформированности общего информационного поля концептов, что выражается в дискретном восприятии рекламного слогана.

Выводы. В контексте теории речевого воздействия первые два этапа воплощения текста слогана-лозунга "Армия. Язык. Вера." в массовое сознание (привлечение к тексту внимания и оптимизация его восприятия) были успешно осуществлены. Ряд причин (экстралингвистического и лингвистического характера, например, использование слов с абстрактной, неконкретной семантикой "язык", "вера") усложнил осуществление третьего этапа (принятие содержания) импликации текста. Концептообразующая номинация "армия", потенциально содержащая негативные смысловые компоненты, вызвала реакции, связанные $c$ возникновением в сознании индивидов когнитивного дисбаланса. Сравнение ассоциатов двух этапов эксперимента показали, что для респондентов важен контекст восприятия слов-стимулов. Так, оценочные коннотации слов-реакций (в частности, касающихся номинации "армия") в контексте рекламной кампании партии П. Порошенка и вне этого контекста существенно различаются.

Ключевые слова: политическая коммуникация, теория речевого воздействия, политические концепты, ассоциативный эксперимент, слоган-лозунг. 